Aleksandar Đorđević ${ }^{1}$

University of Niš, Faculty of Economics
SCIENTIFIC REVIEW ARTICLE doi:10.5937/ekonomika1801095D

Received December, 07, 2017

Accepted: February, 28, 2018

\title{
THE APPLICATION OF ADVANCED TECHNOLOGIES IN THE FIELD OF INTERNATIONAL FINANCES: BITCOIN PHENOMENON ${ }^{2}$
}

\begin{abstract}
During the history there have been different examples of incorporating technology into economics. Some of them include SWIFT, e-banking, mobile payments, and many more. Technology had to be commercialized and put into service of facilitating economic processes. International finances underwent the process of development too. With the globalization process national economies became more interconnected and dependent from each other. Individuals demanded a faster and more convenient way to make international payments. Internet trade is on the rise, social media rule the contemporary world, and then appears the inception of so-called crypto currencies. The most famous is Bitcoin. Where lays its place in the economic science? It looks like that Bitcoin is going towards decentralization of the monetary system known by now. The goal of this paper is to raise the awareness of the changes happening in economy and in economic science.
\end{abstract}

Key words: means of payment, crypto currency, Bitcoin, international finance

JEL classification: $E$ 40, F 30, G 10

\section{ПРИМЕНА НАПРЕДНИХ ТЕХНОЛОГИЈА У ОБЛАСТИ МЕЂУНАРОДНИХ ФИНАНСИЈА: ФЕНОМЕН БИТКОИНА}

Апстракт

Током историје постојало је много примера инкорпорирања технологије у економију. Неки од њих укључују СШИФТ, е-банкарство, мобилна плаћања и многе друге. Морало је доћи до комериијализачије технологије и њеног стављања у службу олакшаға економских процеса. Међународне финансије такође су прошле кроз прочесс развоја. Са процесом глобализаиије наџионалне економије постале су повезаније међусобно и зависне једне од других. Појединци су захтевали бржи и прикладнији начин извршавања међународних плаћања. Интернет трговина је у порасту, друштвени медији владају савременим светом, и ту се појављује настанак тзв. криптовалута. Најпознатија је биткоин. Где се налази његово место у економској науци? Изгледа да биткоин воид ка деценттрализацији монетарног система који нам је познат до сада. Циљ овог

\footnotetext{
1jaleksandar91@gmail.com

${ }^{2}$ The paper is a part of research done within the project funded by the Serbian Ministry of Education, Science and Technological Development: Improving the competitiveness of public and private sector by networking the competencies in the Process of European integration of Serbia, number OI 179066.
} 
рада је да подигне свест о променама које се дешавају у привреди као и у економској науции.

Кључне речи: средства плаћања, крипто валуте, Биткоин, међународне финансије

\section{Introduction}

The main characteristic of the 21 st century is certainly a dominance of information technology. After three industrial revolutions and a fourth upcoming, technology becomes an integral part of our daily lives. The fourth revolution is going a step further as it mentions the integration of technology and humans and embedding technology into human beings. In addition to technology the culture of individualism is highlighted, speed of execution of work, as well as the primary goal of making profit. The end of the 20th and beginning of the 21 st century is also colored with the process of globalization. In short it is the demolition of all barriers, free movement of people, goods, services and capital. Globalization sets in all aspects of social and economic development. Removing the barriers that existed in the communication, promotion of English as a foreign language, the emergence of the Internet, social networks, personal computers, smartphones, all of which contribute to absolute connection and communication between people regardless of their location in the world.

In the previous century, international finance recorded a rapid development. National financial markets are losing the basic attributes and becoming a part of the global financial market. As a result, economic growth and the development of a single economic entity did not depend only on the actions taken by policy makers in national financial markets. New, more complex relationships in the international finances are being established as a result of continuous development of financial globalization and financial integration of national economies. The international monetary system has also seen significant changes. Changing economic mechanisms, rules, rapid development of the world economy causes changes in the functioning of the international monetary system.

There is an analogy between computers and the method of communication on one side and the international payments on the other. Exclusivity and monopoly that once possessed the global television companies or large companies that used computers, global financial institutions currently enjoy in the performance of international payments. But also in this field appeared a tendency towards the individualization and the overtaking the role of the banks. The desire of end-users to take on the role of emission of money from central banks and the control over payments with significantly reduced fees is becoming stronger and stronger. It can be said that the technological revolution, the availability of modern technology, the popularity of the Internet and global communication are necessary prerequisites for the creation of a new phenomenon. Just like this arises the idea of a currency which would be completely independent of the central and commercial banks, monetary authorities, various rules and regulations of the countries. The birth of the idea of crypto currencies can be characterized as a kind of globalization of the international payment system, where perhaps it is more accurately to use the term individualization and privatization instead of globalization. Does, however, this phenomenon of crypto currency carry a new latent form of domination of world powers with the aim of achieving virtual colonization? Are crypto currencies only seemingly exempt from national characteristics? Do we move toward individualization and 
privatization of the currency? The main objective of this paper is to raise the awareness of the existence of crypto currencies, to give a more detailed explanation of their creation and functioning, to identify them in the international monetary and financial system with the help of the most famous and the first virtual currency - Bitcoin. As some call it the gold of 21 . century it will also be compared to real gold.

\section{Defining and functioning of the Bitcoin}

Bitcoin is what is known as a virtual currency. A virtual currency is a mean of payment id est units of the virtual currency represent a value. It is intended for use in payments within a specific virtual community, such as a particular website, or in a network of users with special software for managing the virtual currency and making payments. This type of virtual community can thus be said to resemble a voluntary agreement to use a specific item as a means of payment.

There are a large number of virtual currency schemes that have been built up, and function, in different ways. They can be broken down into different categories depending on the extent to which it is possible to buy and sell the virtual currency. Here, we divide them into virtual currency schemes that are closed, with unidirectional flow and bidirectional flows. In closed virtual currency schemes, the virtual currency can be neither bought nor sold, but only earned and used on certain websites. If the virtual currency can be bought for national currency but not exchanged back, the scheme has a unidirectional flow such as Amazon coins. When the virtual currency can both be bought and sold and used outside of a certain website, the scheme has bidirectional flows. Bitcoin is an example of a scheme with bidirectional flows. However, these categories can overlap (Segendorf, 2014). A further distinction that can be made is whether the virtual currency is centralized or decentralized. As with banknotes and coins, payments with virtual currency units are made by them changing ownership. The ownership structure must therefore be registered somewhere, otherwise it might be tempting for a virtual currency unit holder to duplicate it and use it multiple times. A centralized virtual currency scheme has a centralized ledger to keep track of the changes, and a decentralized means that ledger is distributed to more than one place. Bitcoin is a bidirectional, decentralized virtual currency and can be called crypto-currency.

Bitcoin was created with the appearance of the original article on the 30 . october in 2008. issued by the pseudonym Satoshi Nakamoto. It was never found out who exactly that person or those people who created Bitcoin were. There are doubts about the coherence of the global financial crisis that took place in 2007. and in 2008 spilled over to the real sector and turned into a global economic crisis. However it is unlikely that such a complex system of codes could be created in such a short period of time. It is more likely that this system was created and was waiting for adequate time to appear on the world stage and that the crisis created such an environment. Due to the uncertainty and mistrust in the banking and financial system, an electronic crypto currency appeared that according to the original published article is not controled by any institution but only by the users themselves. This seemed tempting for the investment of capital.

First and foremost Bitcoin is an open source code that is always available to everyone. It is designed as an electronic crypto currency that has a final offer of 21 million units. There is a complex system of creating these currencies, the term used 
is „mining“ the currency. During a period of 10 minutes a block of 25 Bitcoins can be formed. The block size is reduced with the increase of amount already "dug" (mined), and retrieving data for the new Bitcoin is more difficult. Emissions of Bitcoin are fully planned and programmed, and its management is assigned to the network itself, i.e. those computers that perform verification transactions. This algorithm was chosen because it largely approximates the growth rate of extraction of certain minerals such as gold, having a limited amount of Bitcoin that at some point may exist in the system and the maximum amount that can be "excavated". It is assumed that Bitcoin should evolve like gold. At the moment when the excavation is very difficult, its value will be determined by the amount of transactions, as well as the demand for the currency. Bitcoin as a currency is independent of the central banks, the governments and the financial establishment. Some believe that this is an important financial innovation in recent years, and what most definitely attracts attention is the spiraling price of Bitcoin. It's ultimate goal is to become the alternative to existing payment systems as it enables cross-border transactions without interference from the state or central banks and commercial banks and without a fee. There are two ways to become the owner of Bitcoin, the foregoing one is the mining, while the other is to purchases already created (excavated) Bitcoins on many stock markets that operate around the world and trade Bitcoins.

\section{International payments and Bitcoin}

It is very difficult to classify Bitcoin into a certain economic area. There are indications that it can be marked as international payment given that it is being exchanged between residents of different countries. Foreign payments or international payments include all payments and collections between individual persons and legal entities of a country with the persons and entities who are in other countries, regardless of the basis on which the payment is made. In the international payment operations, as opposed to the payment transactions that take place within one country, there is no universal legal tender that is accepted in all countries. Given that there is a large number of currencies, there is a need of conversion, interference of a large number of banks and financial intermediaries, each of them requiring a certain commission. Taking into account the basic characteristics of international payments, which are (Todorović, Marković, 2014, p. 121):

- they represent the counteract of real economic flows;

- they are performed between residents and non-residents;

- they are performed with means of international liquidity and

- they cause a change in the balance of payments.

If the order goes on to consider which of these characteristics Bitcoin has we will see the following. Considering the first characteristic in exchange for Bitcoin it is possible to obtain certain real economic goods or services subject to the restriction that accepting Bitcoin as a substitute for money is still at an early stage and there are still relatively small number of companies that accept payment with this "currency". The fact is that Bitcoin works at the international level and that payments can be made and that they are executed between residents and non-residents, this is also one of the reasons 
of its inception. In the third characteristic there appears to be a certain overlap of terms regarding that a system in which Bitcoin works does the payment using this "currency", but that just shows that Bitcoin itself represents the means of international liquidity. If it is considered that it is used for settling international obligations and it can be said that the means of international liquidity must be accepted by the participants in international trade, or by an international financial institution then it fulfils the third condition. It remains an open question whether the exchange of Bitcoin between residents of the two countries leads to changes in the balance of payments and is that in some way recorded or would it be recorded in the future. From the analysis of the Bitcoin system it cannot be classified with certainty as a system for carrying out international payments.

\section{Bitcoin as a Currency}

The main economic debate surrounding Bitcoin is whether it is a currency or not. The definition of currency is straightforward: a system of money in general use. In order for tender to be considered a currency, it must meet three criteria (Kiyotaki, Wright, 1989):

(1) it must be able to be used for transactions,

(2) it must be able to be used as a unit of account, and

(3) it must be able to store value

The first requirement of a currency is that it can be used for transactions. There are thousands of websites that accept Bitcoin: in December of 2015, there were approximately 200,000 daily Bitcoin transactions per day (Carrick, 2016), but this volume is tiny compared to other currencies. However, there are still many smaller recognized currencies that have far less daily volume. Furthermore, the number of Bitcoins being used for transactions has been increasing for the last 3 years. There is no generally accepted volume or value of a currency that has to be used in transactions for it to be considered a currency. For example, Cambodia, Lao, and Uganda's currencies are less active than Bitcoin, but they are still considered currencies - they are weak currencies, but currencies nevertheless. Although the daily volume of Bitcoin is relatively small, it is still being used on a consistent basis and has seen a drastic increase in use. Overall, it is unclear whether Bitcoin meets the transactional requirement of a currency - it depends on the interpretation of this requirement.

The second requirement of a currency is that is can be used as a unit of account. This is also debatable for Bitcoin. It clearly has unit of account characteristics. First, it is divisible. A Bitcoin can be divided into an infinite number of pieces, and these can be put back together to form a full Bitcoin. Rogojanu and Badea (2014) noted that one of the challenges with Bitcoin is that the number of Bitcoins is limited to 21 million, but Van Alstyne (2014) pointed out that fractional ownership of a Bitcoin is possible; therefore, the 21 million is not a limiting number. Second, Bitcoin is fungible. All Bitcoins are created equally, and they can all be interchanged. Third, it is countable and subject to mathematical operations. Although Bitcoin seems to clearly meet the unit of account requirements, there is still debate on this. The debate primarily revolves around 
Bitcoin's ability to value goods and services; because of its volatility, it has trouble consistently valuing goods and services. Bitcoin displayed substantial volatility from 2008 to 2017 . However, many currencies incur extreme volatility and are still considered currencies (Dornbusch et al. 1995).

The third requirement of a currency is that it be able to be used as a store value of account. Glasser and other researchers from the empirical analysis of Bitcoin users suggest that Bitcoin is more demanded as an asset than as a currency(2014); they found that users are keeping the coins to store up value for future use. This was further substantiated by $\mathrm{Wu}$ and Pandey (2014); they found that Bitcoin is a good investment asset to use for portfolio diversification. This has also been substantiated by several other studies and is in line with the reason that Bitcoin was originally created-which was to offer an alternative currency that would not lose value because of actions taken by government (Nakamoto 2008). Some have argued that Bitcoin's volatility marginalizes its store value. To that point, many investors gauge the credibility of a currency by its stability and ability to be a safe haven when other financial assets are experiencing volatility (Ranaldo and Söderlind 2010).

The state of Bitcoin as a legitimate currency is unclear. It demonstrates the hallmarks of a currency, but its volatility brings into question whether it clearly meets the requirements of a currency. The volatility has been its largest source of criticism, but this is to be expected of a young currency. Many currencies have suffered from high levels of volatility, but the main difference between these currencies and Bitcoin is that Bitcoin is not backed by a government. It is clear that the legitimacy of Bitcoin as a currency will remain ambiguous for the foreseeable future. In order to gain wide acceptance as a currency, it is going to have to continue to grow in use for several more years and not have any more security issues. Bitcoin has also been used for some illegal activities, such as buying guns and drugs, since it is untraceable. Further the whole scheme of cryptocurrency resemble the story of Nigerian fraud where it is expected that you will earn a lot of money for a small investment(Miladinović Bogavac, 2017.). In the meantime, there is evidence that Bitcoin is a useful economic instrument.

\section{Gold and Bitcoin}

Even the creators of the idea of Bitcoin are all the time alluding to its resemblance to gold, ranging from gold-colored coins to be used as a logo of the virtual currency, then to the limited supply, and up to some details such as terms used which include the process of Bitcoin mining, the excavation of currencies, some of the users are called miners and so on... 
Figure 1: Trends in the price of gold last 30 years

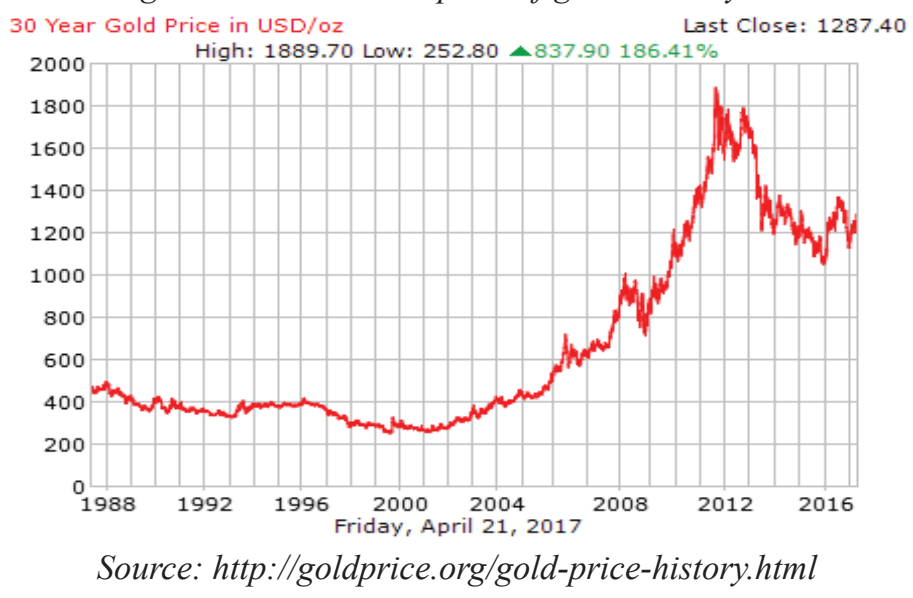

It can be seen that since 2008 there has been a rise in the gold price. This points to a general loss of confidence in the cross-national currency after the financial crisis that occurred this year and the transfer of funds into gold. In many ways, gold is the precious metal counterpart to the Bitcoin. Like the Bitcoin, gold must be obtained through mining. But, while gold is obtained through physical mining, Bitcoins must be "mined" virtually through the deciphering of special computer encryptions. Another similarity is that both gold and Bitcoins are only available in limited quantities. It is estimated that there is approximately 171,000 metric tons of gold in the world, while the Bitcoin system will only be able to generate and support a maximum of 21,000,000 bitcoins until further technological advances are made. Given such similarities and their individual market activity over the past few years, it is understandable why many believe that Bitcoin could ultimately replace gold in terms of value. However, in spite of this evidence, there are a number of reasons why this shift is unlikely to occur. The first reason that the bitcoin will never replace gold is because it still poses a great deal of financial risk. Despite its recent peaks in market value, the bitcoin continues to experience significant price fluctuation that often results in substantial losses. Furthermore, both the future and the viability of the bitcoin have yet to be determined, leaving many customers wary over the the security of their virtual savings in the event that the system becomes terminated or obsolete. With such instability and uncertainty surrounding the bitcoin, it is unlikely that it will generate the customer base to match, much less surpass, gold as an investment asset. Another reason that the bitcoin is unlikely to replace gold as an investment asset is that the system has yet to achieve full status as a truly "universal" and legitimate form of currency. Many countries, including Germany, Norway, Russia, France, Thailand and Korea, refuse to use the bitcoin for fear of potential loss. In fact, several have gone as far as making it illegal in their country. In contrast, there isn't a country in the world that would ignore the value of gold, much less prohibit its use. Therefore, until the bitcoin can reach the same worldwide level of legitimacy and approval that gold has, it will never be able to replace gold as a valuable commodity. The final reason that the bitcoin is unlikely to surpass gold as an investment commodity is that gold has consistently demonstrated signs of recovery since it plummeted by $28 \%$ in 2013 . Many people presumed that the sudden drop in gold's market 
value was an indication that it had lost its status as a safe investment choice. However, a number of signs, such as the increase in debt-to-GDP ratio and the increase in the price of mining, suggest that gold will not only recover from its drop, but it will continue to thrive as a popular investment commodity. Consequently, as long as investors believe that gold can generate profits, they will continue to forgo any other potential replacements.

If we look at comparative price movements of Bitcoin and gold (Figure 4) it shows that the price of Bitcoin at the end of 2013 almost reached the price of one ounce of gold in the market and then launches headlong to mid-2015. After a significant decline and periods of depression Bitcoin price has recorded constant growth and in April 2017, is equated with the price of gold at the end of the month to outpace the price of gold on the market, marking further growth.

Figure 2: Gold and Bitcoin prices

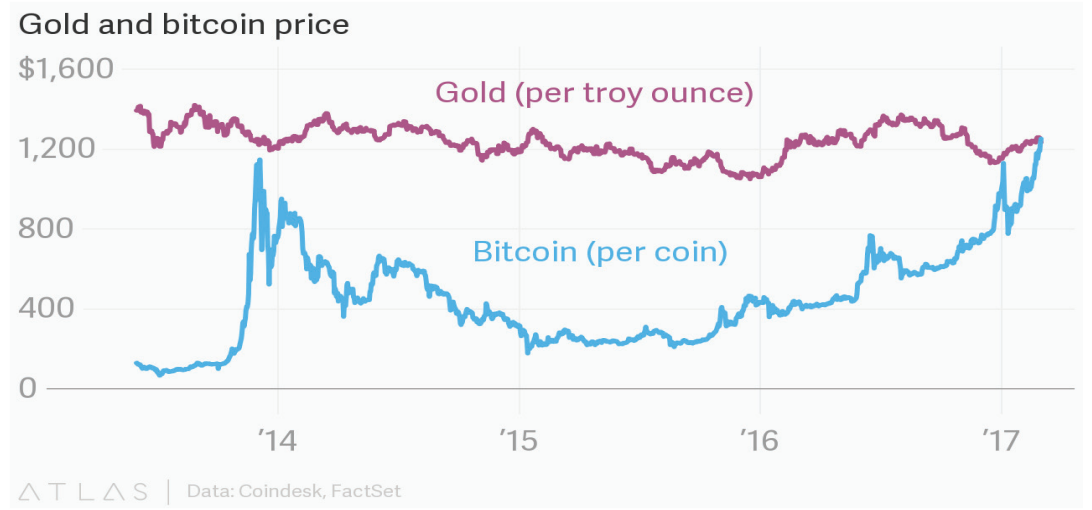

Source: https://www.theatlas.com/charts/B1At3pS9l

The figure clearly shows how the price of Bitcoin is less stable compared to the price of gold, but also clearly we see the moment when first the price of Bitcoin almost caught up with the price of gold, and then after the fall and re-growth caught up with and surpassed the price of gold at the end of this graph. Now the value of Bitcoin is currently over 7.000 dollars with a rising trend in sight.

\section{Conclusion}

Technology is inevitably changing the world we live in. The effects are visible through each aspect of people's lives and economy is not left aside either. The breach of technology into international finance was made a long time ago and is now evolving with the emergence of crypto currencies.

Bitcoin is the most famous and the first crypto currency in the world. This scheme is decentralized virtual currency with two-way flow. It is designed to be independent of the governments, banks and other institutions. Essentially Bitcoin functions as a sort of electronic cash. Emissions of Bitcoin are fully planned and programmed, and its management is assigned to the network and to the end-users. 
There are certain characteristics out of which some stand out: the anonymity of users, non-payment of fees for the transfer of funds, lack of national legislation on this issue, the risk of loss of value due to volatility. Among these characteristics there is no strict division of the advantages and disadvantages as an item can belong to both categories. Certainly it is necessary to mention the abuse of this virtual currency, which was associated with trafficking in illegal goods, financing of terrorist movements, money laundering, tax evasion, but we hope that it will find ways in the future to minimize and eradicate this type of usage.

In the context of the international monetary and financial system Bitcoin can be classified within the scope of international payments as well as the performance of certain functions of money. However specific positioning is not yet possible to perform due to the many uncertainties that are related to this phenomenon. With regard to its status in the national regulations differing from one country to another and moving in the range from full legal invisibility through acceptance as some forms of property, to complete acceptance as proper currency. National Bank of Serbia for example does not recognize Bitcoin as legal tender and warns citizens that they are using this currency on their own responsibility in case of fraud or loss on investment.

The price of this currency shows considerable volatility and steep ups and downs, until the last quarter of consistent growth, catching up and even overtaking the price of gold on the market. It is considered to be the gold of XXI century but it has a long road to conquer the trust of end users that gold has already done. Due to its volatility derivatives of Bitcoin are created to surpass this drawback. It remains unclear, however, what is the future of Bitcoin?

Many questions remain shrouded in mystery: who is behind the Bitcoin phenomenon, who profits from this scheme, and whether it will come to collapse or success... Is this one of the levers of creating "virtual" colonialism mentioned at the beginning? No one can say the last word here, although many things depend on state authorities and financial institutions, as well as on end-users who will decide on the fate of Bitcoin.

\section{References}

Brito J., Houman B. Shadab, Castillo A. (2014), Bitcoin Financial Regulation: Securities, Derivatives, Prediction Markets, and Gambling, Columbia Science and Technology Law Review

Carrick J. (2016), Bitcoin as a Complement to Emerging Market Currencies, Emerging Markets Finance and Trade Volume 52, 2016 - Issue 10, Pages 2321-2334

Charlie Stross. (2013), "Why I want Bitcoin to die in a fire.” Charlie's Diary, December 18. Available online: <http://www.antipope.org/charlie/blog-static/2013/12/ why-i-want-bitcoin-to-die-ina.html $>$.

Chu J, Nadarajah S, Chan S (2015), Statistical Analysis of the Exchange Rate of Bitcoin. PLoS ONE 10(7): e0133678. doi:10.1371/journal.pone.0133678

Coin desk http://www.coindesk.com/data/bitcoin-mining-difficulty-time/ (06.06.2017)

Dong H., Habermeier K., Leckow R.,Haksar V., Almeida Y., Kashima M.,KyriakosSaad N., Oura H., Saadi Sedik T., Stetsenko N, Verdugo-Yepes C., (2016), IMF STAFF DISCUSSION NOTE: Virtual Currencies and Beyond: Initial 
Considerations, INTERNATIONAL MONETARY FUND Monetary and Capital Markets, Legal, and Strategy and Policy Review Departments

Dornbusch R., Goldfajn G., Valdés R., Edwards S., Bruno M., (1995) Currency Crises and Collapses, Brookings Papers on Economic Activity Vol. 1995, No. 2, pp. 219-293

ECB http:/www.ecb.europa.eu/pub/pdf/other/virtualcurrencyschemes201210en.pdf (12.05.2017)

Glaser F., Zimmermann K., Haferkorn M., Moritz C., Siering M., (2014), Bitcoin asset or currency? Revealing users' hidden intentions, Twenty Second European Conference on Information Systems, Tel Aviv

Joshua R. Hendrickson, Thomas L. Hogan, and William J. Luther. (2015). "The Political Economy of Bitcoin.”Working Paper, p. 5. Available online: <http:// papers.ssrn.com/sol3/papers.cfm?abstract_id=2531518>.

Kiyotaki N., Wright R., (1989), On Money as a Medium of Exchange, Journal of Political Economy, Vol. 97, No. 4, pp. 927-954, The University of Chicago Press

Kubát M. (2015), Virtual currency bitcoin in the scope of money definition and store of value, Procedia Economics and Finance vol. 30 p. 409 - 416

Lo S., Wang C. (2014), Bitcoin as money?, Current policy perspectives, Federal Reserve Bank of Boston

Mankiw G., Taylor M.,(2008) Ekonomija, Data status, Beograd

Marković I., Todorović M.,(2017), Spoljnotrgovinsko i carinsko poslovanje, Ekonomski fakultet Niš,

Miladinović Bogavac Ž.,(2017), Business scam in saber space, Ekonomika, Vol. 63, № 4, ISSN 0350-137X, EISSN 2334-9190, UDK 338 (497,1) doi:10.5937/ ekonomika1704097M, p. 97-104

NBS http://www.nbs.rs/internet/latinica/scripts/showContent.html?id=7605 (20.05.2017)

Rogojanu A., Badea L., (2014), The issue of competing currencies.Case study Bitcoin Theoretical and Applied EconomicsVolume XXI (2014), No. 1(590), pp. 103-114

Ranaldo A., Söderlind P., (2010), Safe Haven Currencies, Review of Finance

Satoshi Nakamoto(2008) Bitcoin: A Peer-to-Peer Electronic Cash System www. cryptovest.co.uk

Segendor B. (2014), What is Bitcoin? Sveriges riksbank economic review 2014:2

Todorović M., Marković I., (2013), Međunarodna ekonomija, Ekonomski fakultet Niš,

Van Alstyne M., (2014), Why Bitcoin Has Value, Economic and business dimensions, Communications of the ACM, Vol. 57 No. 5, Pages 30-32, doi: 10.1145/2594288

Wu C., Pandey V., (2014), The Value of Bitcoin in Enhancing the Efficiency of an Investor's Portfolio, Journal of Financial Planning

VRBÍKOVÁ, Lenia a Jan VYSKOČIL(2014). Právní a daňové aspekty Bitcoinu. In: Zkušenosti s virtuálními měnami - Bitcoin měna budoucnosti?. Praha: Vysoká škola manažerské informatiky, ekonomiky a práva, p. 136-139. ISBN 978-8086847-71-9. 